\title{
Recycled Paper \\ Influences \\ Container \\ Substrate Physical \\ Properties, \\ Leachate Mineral \\ Content, and Growth of Rose- of-Sharon and Forsythia
}

\author{
Janet C. Cole ${ }^{1}$ and Lee Newell ${ }^{2}$
}

Additional index words. Forsythia xintermedia, 'Lynwood Gold',

Hibiscus syracus, 'Double Purple', nursery production, peatmoss

Summary. Five container substrates3 pine bark (PB) : 1 peat $(P T): 1$ sand (SD), 3 PB : 1 recycled paper (RP) : 1 SD, 2 PB : 2 RP : 1 SD, 3 vermiculite $(\mathrm{VM}): 1 \mathrm{RP}: 1 \mathrm{SD}$, and $2 \mathrm{VM}: 2$ RP : 1 SD-were used to grow rose-ofsharon (Hibiscus syracus L. 'Double Purple') and forsythia (Forsythia xintermedia Zab. 'Lynwood Gold') for 4.5 months. The control substrate (3 PB:1 PT:1 SD) had higher concentrations of $\mathrm{NH}_{4}^{+}$in leachate than other substrates at each of four sample times during the growing season except 4 Aug. Leaf number and leaf area per plant and height of rose-of-sharon were greater and the leaf area per leaf was smaller in all substrates containing recycled paper than in substrates without recycled paper. Forsythia plants had greater stem and root dry weights and were taller in substrata without recycled paper than plants in substrates with recycled paper. Processed recycled paper is a possible component for container nursery plant production, but further testing on a large number of species is needed before widespread implementation.

${ }^{1}$ Associate professor

${ }^{2}$ Undergraduate student.

Department of Horticulture and Landscape Architecture, Univesity of Oklahoma, Stillwater, OK 74078-6027.

The cost of publishing this paper was defrayed in part by the payment of paae charges. Under postal regulations, this paper therefore must be hereby marked advertisement solely to indicate this fact. 
$\bigcap$ he container growing substrate for plants serves two basic functions: 1) it anchors and supports plants and 2) it provides a reservoir for water and nutrients for plant growth and development (Davidson et al., 1994). A variety of materials are used as components of container growing substrate. The components and proportions of each component used in a particular substrate depend on availability, cost, and plant response. Peatmoss is used commonly as a component of container growing substrates. Peatmoss comes from peat bogs and is considered a slowly renewable resource that eventually will become unavailable. At current mining rates, it has been estimated that 16 million tons of peat could be depleted within 20 years (Cantrell, 1993).

Several studies have been initiated recently to evaluate alternative products as replacements for peat in container mixes. These have included such items as kenaf stem core (Wang, 1994), coir (Meerow, 1994), ground automobile tires (Bowman et al., 1994), and pulp and paper sludge (Chong et al., 1987, Tripepi et al., 1994). The purpose of this study was to evaluate Wet Earth, a patented product that is $80 \%$ recycled paper, $18 \%$ diatomaceous earth, $1 \% \mathrm{CaO}$, and $1 \%$ humic acid and nutrients by volume (CERAD Ind., Oklahoma City, Okla.) as a growing-substrate component. The manufacturing process of WetEarth allows for the use of paraffin-covered boxes and food-contaminated paper products that cannot be recycled otherwise. The mean particle size of Wet Earth is $500 \mu \mathrm{m}$, and it has a greater surface area than comparable products on the market (Harold Manning, personal communication). In 1988, paper and paperboard made up about $40 \%$ (by weight) of the municipal solid waste generated in the United States, while only $14 \%$ of the paper products was recovered through recycling efforts (Kaldjian, 1990). The successful use of spent paper in container substrates would be advantageous to two industries. First, it could provide an inexpensive, permanently available component for container nursery substrates. Second, it could further decrease the waste stream entering our already limited landfill sites. The specific objectives of this study were to determine 1) physical properties of various substrates with recycled paper as a component; 2) substrate effects on leachate electrical conductivity, $\mathrm{pH}$, $\mathrm{N} \mathrm{H}_{4}^{+}, \mathrm{NO}_{3}$, and $\mathrm{P}$; and 3) substrate effects on plant growth and nutrient content.

\section{Materials and methods}

Chemical and physical propetries. The following container growing substrates were prepared (by volume) : 3 pine bark (PB) : 1 peat (PT) : 1 sand $(\mathrm{SD}), 3 \mathrm{~PB}: 1$ recycled paper (RP) (Wet Earth): 1 SD, 2 PB : 2 RP : $1 \mathrm{SD}, 3$ vermiculite (VM) : 1 RP:1 SD, and 2 VM: 2 RP: 1 SD. Each component and each mix (hereafter collectively referred to as substrate) was analyzed for $\mathrm{pH}$ (model 5943-40; Cole Parmer, Chicago) and electrical conductivity (EC) (model SD-B15; Beckman Instrument Co., Cedar Grove, N.J.) using a 2 deionized distilled water : 1 substrate (by volume) extraction method. Bulk density, total porosity, percent air space, and percent water space also were determined (Davies, 1985). Water space was calculated as follows: percent water space $=$ percent porosity - percent air space .

Plant experiment. Fifty $7.5-\mathrm{cm}-$ long (3-inch) rooted cuttings of roseof-sharon and forsythia were planted in 3.8 liter (1 -gal) containers in each of the five substrates described above. All substrates were amended with 1.9 $\mathrm{kg} \cdot \mathrm{m}^{-3}\left(3 \mathrm{lb} / \mathrm{yd}^{3}\right) \mathrm{N}$ as $24 \mathrm{~N}-1.8 \mathrm{P}-$ $5.8 \mathrm{~K}$ controlled-release fertilizer (High $\mathrm{N}$; Scotts Co., Marysville, Ohio) and $0.9 \mathrm{~kg} \cdot \mathrm{m}^{-3}\left(1.5 \mathrm{lb} / \mathrm{yd}^{3}\right)$ Micromax (Scotts Co.). Cuttings were planted on 4 May 1994, placed outside at the Nursery Research Station, Stillwater, Okla., in full sun, and overhead-irrigated daily throughout the growing season with $1.3 \mathrm{~cm}$ (0.5 inch) of water. No supplemental fertilizer was applied during the growing season.

Leachate samples were collected every 3 to 6 weeks as follows. About $2 \mathrm{~h}$ after irrigation, $300 \mathrm{ml}(0.3 \mathrm{qt})$ tap water was applied to the surface of the growing substrate in each container (Wright, 1987). Leachate was collected in a 20.3-cm-diameter (8-inch-diameter) plastic saucer placed under each pot and immediately taken to the lab for analysis. Nutrient contents were determined as follows. $\mathrm{NO}_{3}$ concentration by cadmium reduction method (Page et al., 1982), $\mathrm{NH}_{4}^{+}$using the endophenol blue method (Harwood and Kuhn, 1970), and $P$ using a calorimetric procedure (Page et al., 1982).

Plants were harvested beginning 15 Sept. 1994. Plant heights were measured, leaves were counted, and leaf areas were measured with an area meter (LI-3100; LI-COR, Lincoln,

Table 1. Physical properties of various components used in container growing substrates.

\begin{tabular}{|c|c|c|c|c|c|c|}
\hline Component & pH & $\begin{array}{c}\text { Electrical } \\
\text { conductivity } \\
\left(\mathrm{dS} \cdot \mathrm{m}^{-1}\right)\end{array}$ & $\begin{array}{c}\text { Bulk } \\
\text { density } \\
\left(\mathrm{g} \cdot \mathrm{ml}^{-1}\right)\end{array}$ & $\begin{array}{c}\text { Porosity } \\
(\%)\end{array}$ & $\begin{array}{c}\text { Air } \\
\text { space } \\
(\%) \\
\end{array}$ & $\begin{array}{c}\text { Water } \\
\text { space }^{y} \\
(\%) \\
\end{array}$ \\
\hline Recycled paper (RP) & $8.1 \mathrm{a}^{\mathrm{z}}$ & $1.0 \mathrm{a}$ & $0.39 \mathrm{~b}$ & $69.2 \mathrm{a}$ & $23.0 \mathrm{a}$ & $46.2 \mathrm{~b}$ \\
\hline Sand (SD) & $6.0 \mathrm{~b}$ & $0.0 \mathrm{~b}$ & $1.65 \mathrm{a}$ & $27.0 \mathrm{c}$ & $4.2 \mathrm{~b}$ & $22.8 \mathrm{~d}$ \\
\hline Pine bark (PB) & $3.8 \mathrm{c}$ & $0.1 \mathrm{~b}$ & $0.24 \mathrm{c}$ & $56.6 \mathrm{~b}$ & $30.8 \mathrm{a}$ & $25.8 \mathrm{~d}$ \\
\hline Vermiculite (VM) & $6.0 \mathrm{~b}$ & $0.0 \mathrm{~b}$ & $0.11 \mathrm{~d}$ & $68.0 \mathrm{a}$ & $28.8 \mathrm{a}$ & $39.2 \mathrm{c}$ \\
\hline Peat moss (PM) & $3.6 \mathrm{~d}$ & $0.0 \mathrm{~b}$ & $0.11 \mathrm{~d}$ & $72.4 \mathrm{a}$ & $2.6 \mathrm{~b}$ & $69.8 \mathrm{a}$ \\
\hline
\end{tabular}

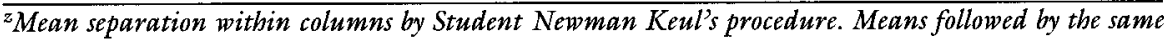
letter are similar $(\mathrm{P}=0.05), n=5$.

${ }^{y}$ Percent water space $=$ percent porosity - percent air space.

Table 2. Physical properties of parious container growing substrates.

\begin{tabular}{lcccccc}
\hline & pH & $\begin{array}{c}\text { Electrical } \\
\text { conductivity } \\
\left(\mathrm{dS} \cdot \mathrm{m}^{-1}\right)\end{array}$ & $\begin{array}{c}\text { Bulk } \\
\text { density } \\
\left(\mathrm{g} \cdot \mathrm{ml}^{-1}\right)\end{array}$ & $\begin{array}{c}\text { Porosity } \\
(\%)\end{array}$ & $\begin{array}{c}\text { Air } \\
\text { space } \\
(\%)\end{array}$ & $\begin{array}{c}\text { Water } \\
\text { space }^{\mathrm{x}} \\
(\%)\end{array}$ \\
\hline 3 PB:1 PT:1 SD & $4.1 \mathrm{e}^{\mathrm{y}}$ & $0.5 \mathrm{~b}$ & $0.59 \mathrm{a}$ & $\mathbf{3 8 . 4} \mathrm{a}$ & $7.9 \mathrm{~b}$ & $30.5 \mathrm{a}$ \\
3 PB:1 RP:1 SD & 6.2 & $0.6 \mathrm{ab}$ & $0.58 \mathrm{a}$ & $40.8 \mathrm{~b}$ & $6.6 \mathrm{~b}$ & $34.2 \mathrm{a}$ \\
$2 \mathrm{~PB}: 2 \mathrm{RP}: 1 \mathrm{SD}$ & $6.9 \mathrm{c}$ & $0.7 \mathrm{ab}$ & $0.59 \mathrm{a}$ & $51.2 \mathrm{ab}$ & $18.2 \mathrm{a}$ & $33.0 \mathrm{a}$ \\
3 VM:1 RP:1 SD & $8.0 \mathrm{a}$ & $0.8 \mathrm{a}$ & $0.62 \mathrm{a}$ & $48.6 \mathrm{ab}$ & $12.1 \mathrm{ab}$ & $36.5 \mathrm{a}$ \\
2 VM:2 RP:1 SD & $7.8 \mathrm{~b}$ & $0.7 \mathrm{ab}$ & $0.43 \mathrm{~b}$ & $57.4 \mathrm{a}$ & $15.3 \mathrm{ab}$ & $42.1 \mathrm{a}$ \\
\hline
\end{tabular}

${ }^{z} P B=$ pine bark, $P T=$ peat moss, $S D=$ sand, $R P=$ recycled paper, $V M=$ vermiculite.

${ }^{y}$ Mean separation within columns by Student Newman Keul's procedure. Means followed by the same letter are similar $(\mathrm{P}=0.05), n=5$.

${ }^{x}$ Percent water space $=$ percent porosity - percent air space. 
Neb.). All medium was washed from the roots with tap water, and leaves, stems, and washed roots were dried at $45 \mathrm{C}$ for 7 days and weighed. Average area per leaf for each plant was calculated by dividing total leaf area by leaf number. Leaf samples then were ground, dry-ashed, and analyzed for elemental concentrations $(\mathrm{K}, \mathrm{Ca}, \mathrm{Mg}$, $\mathrm{Zn}, \mathrm{Fe}$, and $\mathrm{Mn}$ ) using an atomic absorption spectrophotometer (model 2380; Perkin Elmer, Norwalk, Conn.). Leaf samples were also analyzed for ammonia-based $\mathrm{N}$ by the Kjeldahl procedure (Horowitz, 1980) and for $\mathrm{P}$ colorimetrically (Page et al., 1982).

A factorial arrangement of two species and five substrate treatments in a randomized complete-block design consisting of ten plants per substrate treatment and species in five blocks was used. Analysis of variance procedures and Student Newman Keul's procedures were used to determine treatment differences.

\section{Results}

Substrate components differed significantly in all physical properties tested (Table 1). RP had the highest $\mathrm{pH}$ while $\mathrm{PB}$ and $\mathrm{PT}$ had a lower $\mathrm{pH}$ than all other substrates. The EC of RP was also higher than that of any other substrate. The porosity and air space of RP was similar to that of VM, but water space was greater in RP than in VM.

When the components were combined, the differences in physical properties were not so marked. The 3 PB: 1 PT:1 SD had a lower $\mathrm{pH}$ than any other substrate, but EC differed only from 3 VM:1 RP:1 SD (Table 2). The 2 VM:2 RP:1 SD substrate had a lower bulk density than all other substrates; however, its air space and water space did not differ from the other substrates.

There were no significant interactions between species or among substrates in nutrient concentrations in leachate on any sample date. The nutrient concentrations in the leachate collected on 6 May did not differ between the two plant species (Table 3). This would be expected, since samples were taken within $48 \mathrm{~h}$ after planting. Leachate from the control mix (3 PB: 1 PT:1 SD) had the lowest $\mathrm{pH}$ and highest $\mathrm{NH}_{4}^{+}$and $\mathrm{NO}_{3}$ - concentration compared to the other substrate.

On the 31 May leachate samples, species differences were apparent, with

Table 3. $\mathrm{pH}$, electrical conductivity, and concentration of $\mathrm{NH}_{4}^{+}, \mathrm{NO}_{3}^{-}$, and $\mathrm{P}$ present in leachate from rose-of-sharon and forsythia grown in containers with various growing substrates. Samples were collected 6 May 1994.

\begin{tabular}{|c|c|c|c|c|c|}
\hline Treatment & pH & $\begin{array}{c}\text { Electrical } \\
\text { conductivity } \\
\left(\text { dS } \cdot \mathbf{m}^{-1}\right)\end{array}$ & $\begin{array}{c}\mathbf{N H}_{4}^{+} \\
\left(\mathbf{m g} \cdot \text { liter }^{-1}\right) \\
\end{array}$ & $\begin{array}{c}\mathrm{NO}_{3}^{-} \\
\text {(mg.liter }\end{array}$ & $\begin{array}{c}\mathbf{P} \\
\left(\mathrm{mg} \cdot \text { liter }^{-1}\right) \\
\end{array}$ \\
\hline \multicolumn{6}{|c|}{ Species main effect } \\
\hline Rose-of-sharon & $6.5 \mathrm{a}^{\mathrm{z}}$ & $2.1 \mathrm{a}$ & $58.0 \mathrm{a}$ & $41.0 \mathrm{a}$ & $23.3 \mathrm{a}$ \\
\hline Forsythia & $6.4 \mathrm{a}$ & $2.1 \mathrm{a}$ & $76.4 \mathrm{a}$ & $46.6 \mathrm{a}$ & $24.0 \mathrm{a}$ \\
\hline \multicolumn{6}{|c|}{ Substrate main effect } \\
\hline 3 PB:1 PT:1 SD & $4.7 \mathrm{~d}$ & $2.2 \mathrm{a}$ & $158.5 \mathrm{a}$ & $88.6 \mathrm{a}$ & $24.5 \mathrm{a}$ \\
\hline 3 PB:1 RP:1 SD & $6.4 c$ & $2.0 \mathrm{a}$ & $59.0 \mathrm{~b}$ & $49.4 \mathrm{~b}$ & $26.5 \mathrm{a}$ \\
\hline 2 PB:2 RP:1 SD & $6.8 \mathrm{~b}$ & $2.0 \mathrm{a}$ & $48.8 \mathrm{~b}$ & $18.5 \mathrm{c}$ & $25.0 \mathrm{a}$ \\
\hline 3 VM:I RP:I SD & $7.3 \mathrm{a}$ & $2.3 \mathrm{a}$ & $33.4 \mathrm{~b}$ & $26.0 \mathrm{c}$ & $22.1 \mathrm{a}$ \\
\hline $2 \mathrm{VM}: 2 \mathrm{RP}: 1 \mathrm{SD}$ & $7.2 \mathrm{a}$ & $2.2 \mathrm{a}$ & $36.2 \mathrm{~b}$ & $36.6 \mathrm{bc}$ & $20.0 \mathrm{a}$ \\
\hline
\end{tabular}

$\overline{{ }^{z} \text { Mean separation within column and main effect by Student Newman Keul's procedure. Means followed }}$ by the same letter are similar $(\mathrm{P}=0.05)$.

${ }_{Y} P B=$ pine bark, $P T=$ peatmoss, $S D=$ sand, $R P=$ recycled paper, $V M=$ vermiculite.

Table 4. $p \mathrm{H}$, electrical conductivity, and concentration of $\mathrm{NH}_{4}^{+}, \mathrm{NO}_{3}^{-}$, and P present in leachate from rose-of-sharon and forsythia grown in containers with various growing substrates. Samples pere collected 31 May 1994.

\begin{tabular}{|c|c|c|c|c|c|}
\hline Treatment & pH & $\begin{array}{c}\text { Electrical } \\
\text { conductivity } \\
\left(\mathrm{dS} \cdot \mathrm{m}^{-1}\right) \\
\end{array}$ & $\begin{array}{c}\mathrm{NH}_{4}^{+} \\
\left(\mathrm{mg} \cdot \mathbf{l i t e r}^{-1}\right) \\
\end{array}$ & $\begin{array}{c}\mathrm{NO}_{3}^{-} \\
\left(\mathrm{mg}^{-} \text {liter }\right. \\
\end{array}$ & $\begin{array}{c}\mathbf{P} \\
\left(\mathrm{mg} \cdot \mathrm{liter} \mathbf{1}^{-1}\right)\end{array}$ \\
\hline \multicolumn{6}{|c|}{ Species main effect } \\
\hline Rose-of-sharon & $6.5 b^{z}$ & $1.1 \mathrm{a}$ & $15.1 \mathrm{a}$ & $45.7 \mathrm{a}$ & $6.7 \mathrm{~b}$ \\
\hline Forsythia & $6.6 \mathrm{a}$ & $1.2 \mathrm{a}$ & $4.1 \mathrm{~b}$ & 45.7 a & $14.1 \mathrm{a}$ \\
\hline \multicolumn{6}{|c|}{ Substrate main effect } \\
\hline 3 PB:1 PT:1 SD & $5.9 \mathrm{e}$ & $1.01 \mathrm{c}$ & $18.8 \mathrm{a}$ & $32.1 \mathrm{~b}$ & $5.0 \mathrm{c}$ \\
\hline $3 \mathrm{~PB}: 1 \mathrm{RP}: 1 \mathrm{SD}$ & $6.3 \mathrm{~d}$ & $1.10 \mathrm{bc}$ & $5.0 \mathrm{~b}$ & $36.8 \mathrm{~b}$ & $11.7 \mathrm{ab}$ \\
\hline 2 PB:2 RP:1 SD & $6.6 \mathrm{c}$ & $1.18 \mathrm{bc}$ & $11.6 \mathrm{ab}$ & $43.2 \mathrm{~b}$ & $13.0 \mathrm{ab}$ \\
\hline $3 \mathrm{VM}: 1 \mathrm{RP}: 1 \mathrm{SD}$ & $7.0 \mathrm{a}$ & $1.24 \mathrm{ab}$ & $7.5 \mathrm{ab}$ & $52.1 \mathrm{ab}$ & $7.8 \mathrm{c}$ \\
\hline 2 VM:2 RP:1 SD & $6.8 \mathrm{~b}$ & $1.37 \mathrm{a}$ & $5.3 \mathrm{~b}$ & $64.3 \mathrm{a}$ & $14.8 \mathrm{a}$ \\
\hline
\end{tabular}

$\overline{{ }^{z} \text { Mean separation within column and main effect by Student Newman Keul's procedure. Means followed }}$ by the same letter are similar $(\mathrm{P}=0.05)$.

yPB $=$ pine bark, $P T=$ peatmoss, $S D=$ sand, $R P=$ recycled paper, $V M=$ permiculite.

Table 5. pH, electrical conductivity, and concentration of $\mathrm{NH}_{4}^{+}, \mathrm{NO}_{3}^{-}$, and $\mathrm{P}$ present in leachate from rose-of-sharon and forsythia grown in containers with various growing substrates. Samples pere collected 12 July 1994.

\begin{tabular}{|c|c|c|c|c|c|}
\hline Treatment & $\mathbf{p H}$ & $\begin{array}{c}\text { Electrical } \\
\text { conductivity } \\
\left(\mathrm{dS} \cdot \mathrm{m}^{-1}\right)\end{array}$ & $\begin{array}{c}\mathrm{NH}_{4}{ }^{+} \\
\left(\mathrm{mg}^{-1}{ }^{-1}{ }^{-1}\right) \\
\end{array}$ & $\begin{array}{c}\mathrm{NO}_{3}^{-} \\
\left(\mathrm{mg}^{-} \mathrm{liter}^{-1}\right)\end{array}$ & $\begin{array}{c}\mathrm{P} \\
\left(\mathrm{mg} \cdot \text { liter }^{-1}\right)\end{array}$ \\
\hline \multicolumn{6}{|c|}{ Species main effect } \\
\hline Rose-of-sharon & $6.3 \mathrm{a}^{2}$ & $1.9 \mathrm{a}$ & $45.0 \mathrm{a}$ & $74.4 \mathrm{a}$ & $10.5 \mathrm{a}$ \\
\hline Forsythia & $6.3 \mathrm{a}$ & $1.7 \mathrm{a}$ & $5.7 \mathrm{~b}$ & $82.0 \mathrm{a}$ & $7.0 \mathrm{~b}$ \\
\hline \multicolumn{6}{|c|}{ Substrate main effect } \\
\hline 3 PB:1 PT:1 SD & $5.7 \mathrm{~d}$ & $2.0 \mathrm{a}$ & 87.8 a & $80.0 \mathrm{a}$ & $1.2 \mathrm{~b}$ \\
\hline 3 PB:I RP:I SD & $6.1 \mathrm{c}$ & $1.9 \mathrm{a}$ & $17.7 \mathrm{~b}$ & $73.6 \mathrm{a}$ & $9.9 \mathrm{a}$ \\
\hline 2 PB:2 RP:1 SD & $6.4 c$ & $1.9 \mathrm{a}$ & $17.1 \mathrm{~b}$ & $81.6 \mathrm{a}$ & $11.4 \mathrm{a}$ \\
\hline 3 VM:1 RP:I SD & $6.6 \mathrm{a}$ & $1.8 \mathrm{a}$ & $0.0 \mathrm{~b}$ & $62.4 \mathrm{a}$ & $8.8 \mathrm{a}$ \\
\hline 2 VM:2 RP:1 SD & $6.5 \mathrm{ab}$ & $1.9 \mathrm{a}$ & $4.0 \mathrm{~b}$ & $73.6 \mathrm{a}$ & $1.2 \mathrm{~b}$ \\
\hline
\end{tabular}

${ }_{{ }^{z} \text { Mean separation within column and main effect by Student Newman Keul's procedure. Means followed }}$ by the same letter are similar $(\mathrm{P}=0.05)$.

${ }_{P} P B=$ pine bark, $P T=$ peatmoss, $S D=$ sand,$R P=$ recycled paper, $V M=$ vermiculite.

leachate from rose-of-sharon having a lower $\mathrm{pH}$ and $\mathrm{P}$ concentration and a higher $\mathrm{NH}_{4}^{+}$concentration than leachate from forsythia (Table 4), indi- eating a possible difference in plant uptake of nutrients. The control substrate (3 PB:1 PT:1 SD) released leachate with higher concentrations of 
Table 6. Plant growth characteristics of rose-of-sharon and forsytbia grown in various substrates.

\begin{tabular}{|c|c|c|c|c|c|c|c|}
\hline \multirow[b]{2}{*}{ Substrate $^{2}$} & \multirow{2}{*}{$\begin{array}{c}\text { Leaves/ } \\
\text { plant }\end{array}$} & \multicolumn{2}{|c|}{ Leaf area $\left(\mathrm{cm}^{2}\right) /$} & \multicolumn{3}{|c|}{ Dry wt $(\mathrm{g})$} & \multirow{2}{*}{$\begin{array}{c}\mathrm{Ht} \\
(\mathrm{cm})\end{array}$} \\
\hline & & Leaf & Plant & Leaf & Stem & Root & \\
\hline & & \multicolumn{2}{|c|}{ Rose-of-sharon } & & 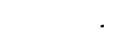 & & \\
\hline 3 PB:1 PT:1 SD & $77.0 \mathrm{c}^{y}$ & $2.7 \mathrm{a}$ & $200.4 \mathrm{~b}$ & $1.9 \mathrm{~b}$ & $6.5 \mathrm{~d}$ & $7.8 \mathrm{a}$ & $25.1 \mathrm{~d}$ \\
\hline 3 PB:1 RP:1 SD & $170.5 \mathrm{ab}$ & $2.1 \mathrm{~b}$ & $345.5 \mathrm{a}$ & $2.7 \mathrm{a}$ & $9.9 c$ & $7.9 \mathrm{a}$ & $35.6 \mathrm{c}$ \\
\hline $2 \mathrm{~PB}: 2 \mathrm{RP}: 1 \mathrm{SD}$ & $169.0 \mathrm{ab}$ & $2.1 \mathrm{~b}$ & $344.9 \mathrm{a}$ & $3.0 \mathrm{a}$ & $12.2 \mathrm{~b}$ & $8.5 \mathrm{a}$ & $39.9 \mathrm{~b}$ \\
\hline 3 VM:1 RP:I SD & $192.0 \mathrm{a}$ & $1.9 \mathrm{~b}$ & $341.6 \mathrm{a}$ & $3.0 \mathrm{a}$ & $14.0 \mathrm{a}$ & $8.8 \mathrm{a}$ & 43.7 a \\
\hline $2 \mathrm{VM}: 2 \mathrm{RP}: 1 \mathrm{SD}$ & $161.3 \mathrm{~b}$ & $2.0 \mathrm{~b}$ & $\begin{array}{l}306.9 \text { a } \\
\text { ythia }\end{array}$ & $3.0 \mathrm{a}$ & $12.2 \mathrm{~b}$ & $8.4 \mathrm{a}$ & $41.2 \mathrm{ab}$ \\
\hline 3 PB:1 PT:1 SD & $283.3 \mathrm{a}$ & $3.7 \mathrm{a}$ & $1023.8 \mathrm{a}$ & $9.5 \mathrm{a}$ & $15.0 \mathrm{a}$ & $19.7 \mathrm{a}$ & $80.4 \mathrm{a}$ \\
\hline 3 PB:1 RP:1 SD & $231.4 \mathrm{a}$ & $3.6 \mathrm{a}$ & $824.9 \mathrm{a}$ & $7.4 \mathrm{ab}$ & $9.9 \mathrm{~b}$ & $13.3 \mathrm{~b}$ & $64.3 \mathrm{~b}$ \\
\hline 2 PB:2 RP:1 SD & $235.3 \mathrm{a}$ & $3.5 \mathrm{a}$ & $785.7 \mathrm{a}$ & $6.6 \mathrm{~b}$ & $10.6 \mathrm{~b}$ & $12.9 \mathrm{~b}$ & $62.3 \mathrm{~b}$ \\
\hline 3 VM:1 RP:I SD & $234.6 \mathrm{a}$ & $3.5 \mathrm{a}$ & 811.1 a & $7.4 \mathrm{ab}$ & $10.3 \mathrm{~b}$ & $13.4 \mathrm{~b}$ & $70.3 \mathrm{ab}$ \\
\hline 2 VM:2 RP:1 SD & $281.3 \mathrm{a}$ & $3.6 \mathrm{a}$ & $1002.6 \mathrm{a}$ & $8.3 \mathrm{ab}$ & $11.7 \mathrm{~b}$ & $16.2 b^{-\cdots}$ & $74.0 \mathrm{ab}$ \\
\hline
\end{tabular}

${ }^{2} P B=$ pine bark, $P T=$ peatmoss, $S D=$ sand, $R P=$ recycled paper, $V M=$ vermiculite.

${ }^{y}$ Mean separation within column and species by Student Newman Keul's procedure. Means followed by the same letter are similar $(\mathrm{P}=0.05)$.

$\mathrm{N} \mathrm{H}_{4}^{+}$than 3 PB:1 RP:1 SD and 2 VM:2 RP:1 SD. The leachate from 3 PB:1 PT:1 SD had lower $\mathrm{NO}_{3}$ and $\mathrm{P}$ than 2 VM:2 RP:1 SD and less P than either of the other two substrates containing PB.

On the 12 July samples, the concentration of $\mathrm{NH}_{4}^{+}$and $\mathrm{P}$ was greater in leachate from rose-of-sharon than in leachate from forsythia (Table 5). The leachate from the control substrate contained high concentrations of $\mathrm{NH}_{4}^{+}$compared to all other substrates. The leachate from the $3 \mathrm{~PB}: 1$ PT:1 SD also contained less P compared to the other substrates except 2 VM:2 RP:1 SD.

By 4 Aug., leachate from the pots was unaffected by species or substrate, except that the $\mathrm{pH}$ of $3 \mathrm{~PB}: 1 \mathrm{PT}: 1 \mathrm{SD}$ was 6.2 and lower than any other substrate.

At harvest, rose-of-sharon grown in 3 PB:1 PT:1 SD had fewer leaves and a smaller leaf area per plant, but a greater leaf area per leaf and a smaller height than in any other substrate treatment (Table 6). Leaf and stem dry weights of rose-of-sharon plants in all substrate treatments that included RP were greater than those of plants in the 3 PB:1 PT:1 SD control mix. Rose-ofsharon root dry weights were similar regardless of substrate treatment.

Forsythia leaf characteristics were similar among the various substrates (Table 6); however, plants grown in 3 PB:1 PT:1 SD had greater stem and root dry weights than plants in any other substrate treatment. Forsythia in 3 PB:1 PT:1 SD were taller than those grown in either of the other substrate containing $\mathrm{PB}$.
Leaf tissue elemental concentration of rose-of-sharon and forsythia were unaffected by substrate (data not shown).

\section{Discussion}

The various substrate components and substrates differed in several physical properties, which may have contributed to differences in plant growth of the two species tested. Generally, both of these species are considered adaptable to a variety of soil conditions (Dirr, 1994). While there were differences in $\mathrm{NH}_{4}^{+}, \mathrm{NO}_{3}^{-}$, and $\mathrm{P}$ in leachate at the various test times, no differences occurred in leaf elemental content at the end of the growing season. The leaf elemental content was within acceptable ranges for all macro- and micronutrients tested. This indicates that the fertility in each substrate was comparable in supporting plant responses. Chong et al. (1987) determined that leaf elemental content of spiraea plants grown in substrate containing paper sludge also was within acceptable ranges. Unlike the plants in this study, the spiraea foliage had a dark bluegreen sheen that is symptomatic of excess $\mathrm{N}$.

While there was no difference in leaf elemental contents, there was a difference in $\mathrm{pH}$ among the substrates. Those substrates containing RP had a higher $\mathrm{pH}$ than the control substrate. The $\mathrm{pH}$ of a substrate can affect nutrient availability, which may account for some of the differences in plant growth.

The rose-of-sharon plants were taller in all substrates with recycled paper compared to those in the substrate without the recycled paper. Taller plants could be advantageous to growers since consumers often look for larger, high-quality plants to purchase. The forsythia plants were smaller in substrates containing recycled paper than those in substrate without the recycled paper. While decreased plant size is a concern to the grower, it is not necessarily a problem. Forsythia generally requires pruning several times during the growing season in container production. If plants could be kept at a smaller size without affecting plant quality, it would reduce the need for pruning and save labor costs during production.

From this study, we conclude that processed recycled paper is a possible component for container nursery plant production. Plant response varied with species thus further testing on a large number of species is needed.

\section{Literature Cited}

Bowman, D.C., R.Y. Evans, and L.L. Dodge. 1994. Growth of chrysanthemum with ground automobile tires used as a container soil amendment. HortScience 29:774-776.

Cantrell, R.L. 1993. Peat-1992. Annu. Rpt. U.S. Dept. of the Interior, Bur. of Mines.

Chong, C., R.A. Cline, and D.L. Rinker. 1987. Spent mushroom compost and papermill sludge as soil amendments for containerized nursery crops. Proc. Intl. Plant Prop. Soc. 37:347-353.

Davidson, H., R. Mecklenburg, and C. Peterson. 1994. Nursery management administration and culture. Prentice Hall, Englewood Cliffs, N.J., 
Davies, Jr., F.T. 1985. Nursery Production and management lecture and laboratory manual. 3rd ed. Texas A\&M Univ., College Station.

Dirr, M.A. 1994. Manual of woody landscape plants: Their identification, ornamental characteristics, culture, propagation and uses. 4th ed. Stipes Publishing, Champaign, Ill.

Harwood, J.E. and A.L. Kuhn. 1970. A colorimetric method for ammonia in natural waters. Water Res. 4:805-811.

Horowitz, W. 1980. Official methods of analysis of the Association of Official Analytical Chemists. 13th ed. Assn. Official Analytical Chemists, Washington, D.C. p. 15, section 2.058 .

Kaldjian, P. 1990. Characterization of municipal solid waste in the United States: 1990 update. U.S. Environ. Protection Agency Dec. 530-SW-90-042.
Meerow, A.W. 1994. Growth of two subtropical ornamentals using coir (coconut mesocarp pith) as a peat substitute. HortScience 29:1484-1486.

Page, A.L., R.H. Miller, and D.R. Keeney. 1982. Methods of soil analysis. Part 2. Chemical and microbiological properties. Amer. Soc. Agron.-Soil Sci. Soc. Amer., Madison, Wis.

Tripepi, R.R., M.W. George, and A.G. Campbell. 1994. Evaluating pulp and paper sludge as a substitute for peatmoss in container media. HortScience 29:551. (Abstr.).

Wang, Y.T. 1994. Using ground kenaf stem core as a major component of container media. J. Amer. Soc. Hort. Sci. 119:931-935.

Wright, R.D. 1987. The Virginia Tech extraction method. Proc. Southern Nurseryman's Res. Conf. 32:68-69. 